\title{
Mitral valve regurgitation due to annular dilatation caused by a huge and floating left atrial myxoma
}

\author{
Mehmet Kaya, Burak Ersoy, Mehmet Yeniterzi \\ Mehmet Akif Ersoy Thoracic and Cardiovascular Training and Research Hospital, Istanbul, Turkey \\ Kardiochirurgia i Torakochirurgia Polska 2015; 12 (3): 248-250
}

\begin{abstract}
We describe a case of mitral valve annular dilatation caused by a huge left atrial myxoma obstructing the mitral valve orifice. A 50-year-old man presenting with palpitation was found to have a huge left atrial myxoma protruding into the left ventricle during diastole, causing severe mitral regurgitation. The diagnosis was made with echocardiogram. Transoesophageal echocardiography revealed a solid mass of $75 \times 55 \mathrm{~mm}$. During operation, the myxoma was completely removed from its attachment in the atrium. We preferred to place a mechanical heart valve after an annuloplasty ring because of severely dilated mitral annulus and chordae elongation. The patient had an uneventful recovery. Our case suggests that immediate surgery, careful evaluation of mitral valve annulus preoperatively is recommended.

Key words: huge atrial myxoma, mitral regurgitation, annular dilatation.
\end{abstract}

\section{Introduction}

The mitral annulus plays a crucial role in leaflet coaptation [1]. A number of disorders, including functional and ischaemic mitral regurgitation, mitral valve prolapse, and atrial fibrillation, can cause annular dysfunction. Large dilatation of the mitral annulus due to a huge left atrial myxoma is a rare cause of mitral regurgitation [2].

Herein, we present a case of mitral valve annular dilatation caused by a huge left atrial myxoma protruding into the left ventricle.

\section{Case report}

A 50-year-old male patient presented to our hospital with progressive palpitation for the preceeding two weeks. The patient's physical examination and laboratory param-

\section{Streszczenie}

W pracy przedstawiono przypadek dylatacji pierścienia zastawki mitralnej spowodowanej przez śluzaka lewego przedsionka blokującego ujście zastawki mitralnej. Mężczyzna, lat 50, zgłosił się z objawami palpitacji serca. Rozpoznano u niego olbrzymiego śluzaka lewego przedsionka wysuwającego się do lewej komory w czasie rozkurczu i powodującego ciężką niedomykalność zastawki mitralnej. Rozpoznanie ustalono na podstawie echokardiogramu. Przezprzełykowa echokardiografia ujawniła obecność litej masy o wymiarach $75 \times 55 \mathrm{~mm}$. W czasie wykonanego zabiegu śluzak został całkowicie usunięty z miejsca przyczepu guza w przedsionku. Podjęto decyzję o implantowaniu mechanicznej zastawki serca za pierścieniem annuloplastycznym ze względu na ciężką dylatację pierścienia mitralnego i wydłużenie strun ścięgnistych serca. Powrót do zdrowia pacjenta przebiegał bez powikłań. Prezentowany przypadek sugeruje, że postępowaniem rekomendowanym $w$ takich sytuacjach powinna być niezwłoczna operacja chirurgiczna po uważnej przedoperacyjnej ocenie pierścienia zastawki mitralnej.

Słowa kluczowe: olbrzymi śluzak przedsionka, niewydolność zastawki mitralnej, dylatacja pierścienia.

eters were normal except for cardiac auscultation revealing 2/6 apical murmur. Transesophageal echocardiogram (TEE) revealed a mass of $75 \times 55 \mathrm{~mm}$ attached to the interatrial septum with a pedicle that almost filled the left atrium. The mass was floating and prolapsed into the left ventricle through the mitral orifice during diastole, causing severe mitral regurgitation. The diameter of the mitral annulus was measured as $52 \mathrm{~mm}$ by TEE (Fig. 1A). Surgery was planned urgently to remove the mass and for evaluation of the mitral valve.

Via a median sternotomy, cardiopulmonary bypass (CPB) was conducted using aortic cannulation and bicaval cannulation, moderate hypothermia, and isothermic blood cardioplegic arrest. The mass was reached through an atrial transseptal incision. The pedicle of a mass was detected near the fossa ovalis. The mass with its pedicle was resect-

Address for correspondence: Mehmet Kaya, Mehmet Akif Ersoy Thoracic and Cardiovascular Training and Research Hospital, Halkali, 34000 Istanbul, Turkey, phone: +905302243476 , e-mail: drmehmetkaya@yahoo.com 

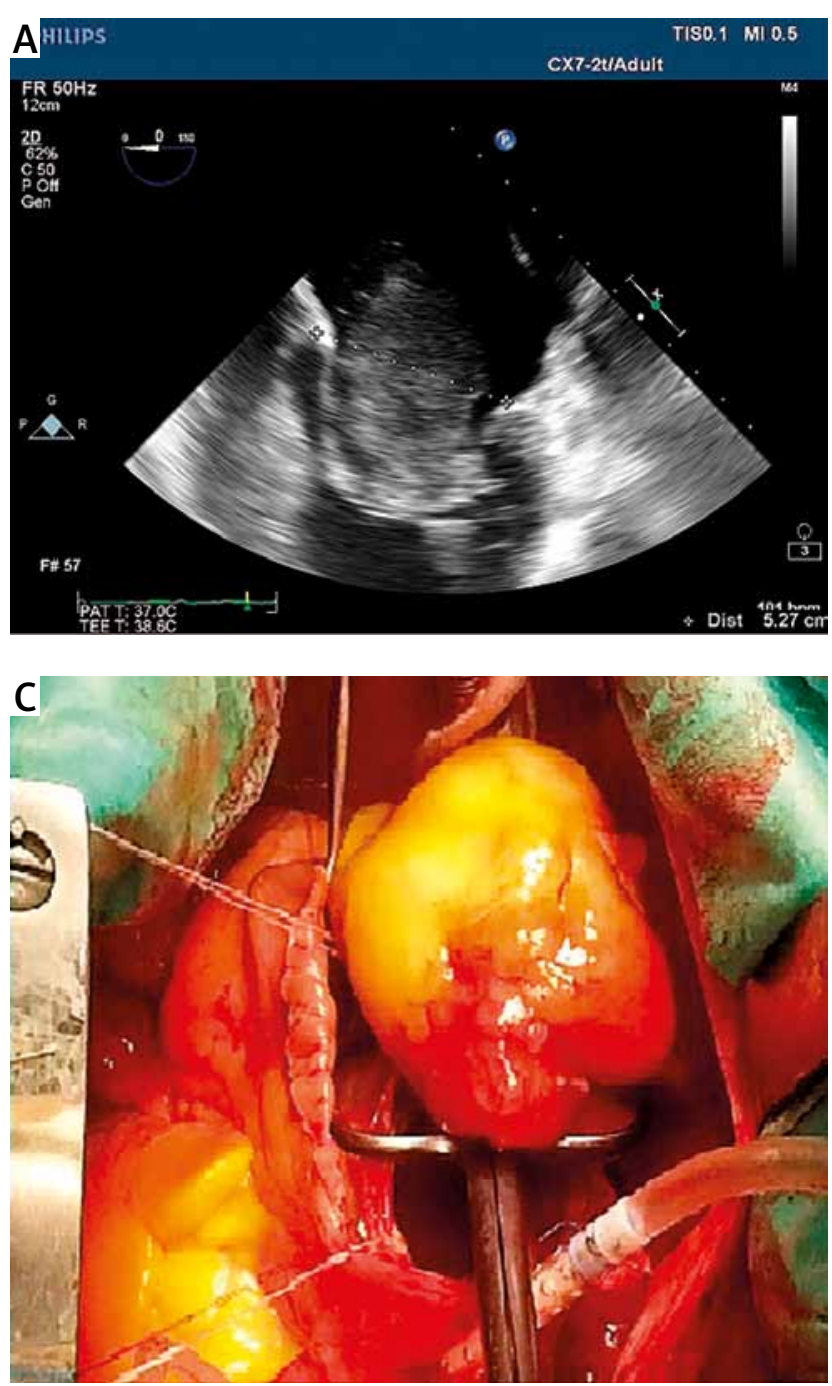

Fig. 1. A) Transesophageal echocardiogram. B) The resected left atrial myxoma measures $75 \times 55 \times 35 \mathrm{~mm}$. C) Intraoperative view of the mass

ed completely (Fig. 1B and C). Intraoperatively (after atrial mass resection and ring annuloplasty) TEE was performed and severe mitral valve failure was noticed, then a $33-\mathrm{mm}$

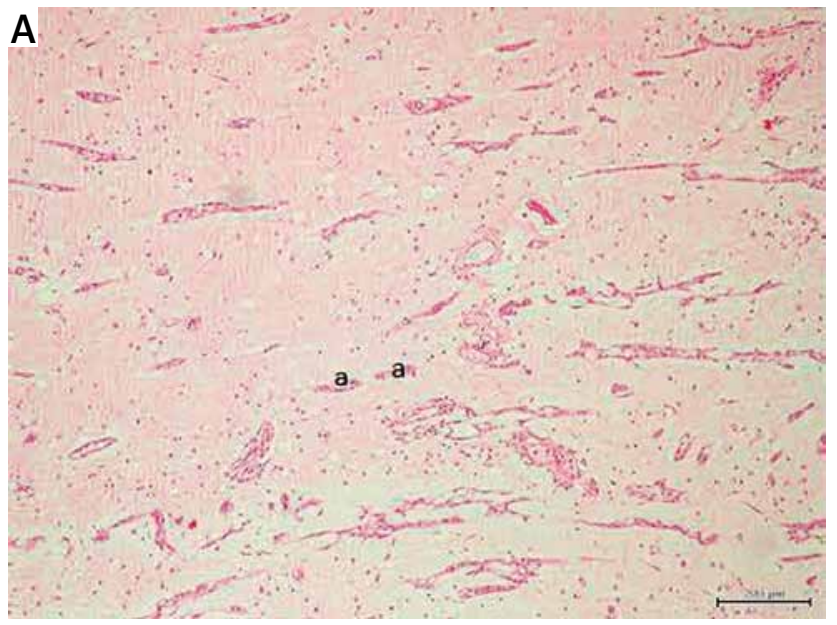

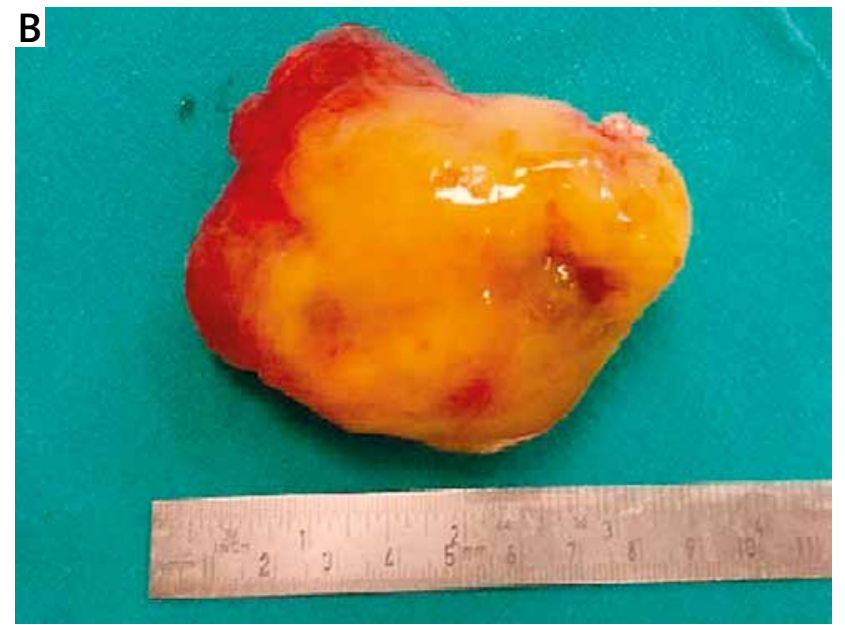

ATS (ATS Medical Minneapolis, MN) mechanical heart valve was placed into the mitral position. The interatrial septum was closed primarily. Sinus rhythm was achieved. Postoperative period was uneventful and the patient was discharged home during the fifth day post-surgery.

The mass was macroscopically round, yellow, $75 \times 55 \times$ $35 \mathrm{~mm}$ in diameter (Fig. 1B). Histological examination was performed by using haematoxylin and eosin stain. The histopathological sample was consistent with myxoma (Fig. 2A and B). The mass had a small pedicle. Visually, no thrombus was detected on the mass.

\section{Discussion}

Myxomas are the most common primary cardiac tumours [3]. About $80-85 \%$ of myxoma are located in the left atrium and usually arise from the interatrial septum [4]. In our case report a patient's myxoma was located in the left atrium.

Myxomas develop slowly, and due to this reason they are asymptomatic in the early stages. Although our patient had a huge atrial myxoma and severe mitral regurgitation he had not experienced any symptoms for a long time.

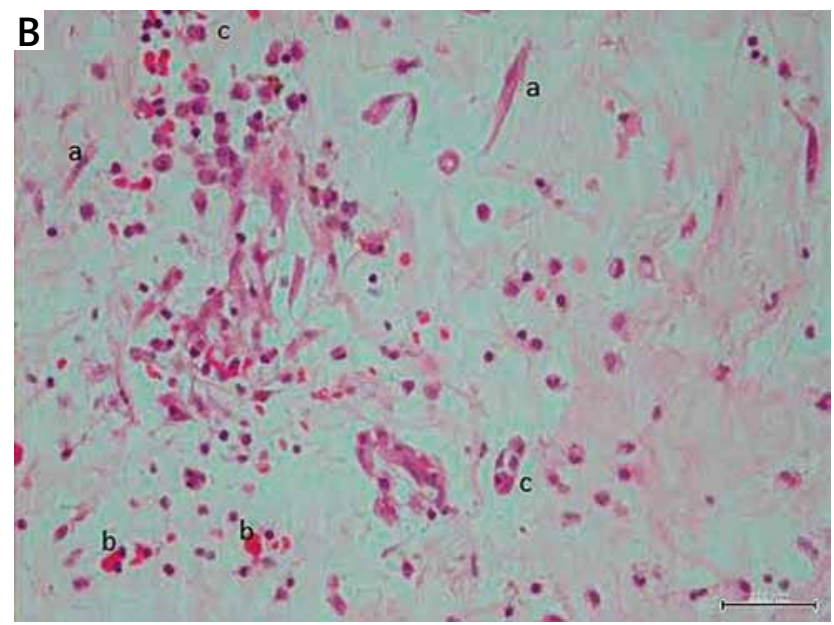

Fig. 2. Histopathological specimens (haematoxylin and eosin stain 20x) 
Transthoracic echocardiography remains a useful tool both at diagnosis and postoperative follow-up. It also helps to diagnose concomitant cardiac pathologies such as mitral regurgitation, which can be caused by myxoma, as in our case.

A lot has been written about myxoma in recent reports. Correspondingly, immediate surgical treatment is not obvious for asymptomatic patients. But It is impossible to know if a huge myxoma is going to get worse in the course of time. Some reports advise that the friable nature of the myxoma itself tends to cause embolism. Thereof, it may be difficult to decide whether surgery should be performed immediately, even in asymptomatic cases. Although myxomas are usually benign histopathologically we believe that surgical treatment is urgently necessary to prevent embolic events, especially in patients with a huge myxoma. The clinical effects of atrial myxoma are not well understood, but it is thought to be mortal in the long term. For this reason, even if the patients are asymptomatic, surgical intervention must be considered when diagnosed. Patients can also experience mitral valve regurgitation and/or stenosis depending on the location of myxoma in the left atrium.

Another issue, floating or large left atrial myxoma, may affect transmitral valve flow and hide severe mitral regurgitation. However, a severe mitral regurgitation was noticed in our case during the preoperative echocardiogram. For this reason, we thought that the circumference of mitral annulus was quite broad compared to how it should be. After the ring annuloplasty procedure we intraoperatively performed TEE, which revealed a continuity of mitral valve failure; it was for this reason that the mitral valve was replaced. On the other hand, to deal with a greatly dilated mitral annulus might be problematic because of probable residual annular dilatation, a leaflet problem causing more stress on the rings, or increased tension on suture lines [5].
Several atrial incisions might be used for surgical exposure of the mass. Also, minimally invasive mitral valve procedures through right lateral minithoracotomy might be an effective alternative to full sternotomy for removal of the mass or in mitral valve surgery. But we chose a transatrial approach to obtain better exposure of the mitral valve, the subvalvular apparatus, and the mass.

As in our case, patients can sometimes remain asymptomatic even though the myxoma enlarges to a huge diameter in the left atrium causing severe mitral regurgitation. Prognosis is excellent after successful surgical resection of the myxoma. Recurrence and mortality rates are very low in long-term follow up. Consequently, annular dilatation by itself appears great enough to cause mitral regurgitation with mechanical effect to the mitral valve in patients with giant myxoma.

\section{Disclosure}

Authors report no conflict of interest.

\section{References}

1. Silbiger JJ. Anatomy, mechanics, and pathophysiology of the mitral annulus. Am Heart J 2012; 164:163-176.

2. Sugimoto T, Ogawa K, Asada T, Mukohara N, Nishiwaki M, Higami T. Surgical treatment of left atrial myxoma with concomitant acquired heart disease. Nihon Kyobu Geka Gakkai Zasshi 1993; 41: 660-666.

3. Vilela EP, Moura L, Pepe D, Nunes E, Erthal F, Campana E. Giant atrial myxoma mimicking severe mitral stenosis in young patient. Arq Bras Cardiol 2010; 95: 125-127.

4. Nishizaki Y, Yamagami S, Myojin M, Sesoko M, Yamashita H, Suzuki R, Daida $\mathrm{H}$. A murmur-free giant myxoma discovered incidentally on abdominal ultrasonography. Intern Med 2013; 52: 2529-2531.

5. Matsushita T, Huynh AT, Singh T, Hayes P, Armarego S, Seah PW. Mitral valve annular dilatation caused by left atrial myxoma. Heart Lung Circ 2009; 18: 145-147. 